https://doi.org/10.19195/0524-4544.331.2

\author{
BARBARA ADAMIAK \\ ORCID: 0000-0001-8942-0543 \\ Uniwersytet Wrocławski \\ barbara.adamiak@uwr.edu.pl
}

\title{
Instytucje prawne gwarancji zgodności z prawem jako niepomijalny element regulacji prawa administracyjnego
}

\begin{abstract}
Abstrakt: W prawie administracyjnym niepomijalnym elementem jego regulacji są instytucje prawne gwarancji zgodności z prawem działania administracji publicznej. W prawie ustrojowym regulacja instytucji kontroli i dopuszczalności stosowania środków nadzoru gwarantuje działanie zgodne z prawem. Wprowadzona jest zarówno w regulacji ustrojowej administracji rządowej, jak i regulacji ustrojowej samorządu terytorialnego.

W materialnym prawie administracyjnym niepomijalność regulacji instytucji prawnych gwarancji zgodności z prawem co do zasady należy łączyć z regulacją w procesowym prawie administracyjnym. To w prawie procesowym zawarta jest bowiem regulacja sankcji za naruszenie przepisów prawa materialnego. Nie oznacza to, że w materialnym prawie administracyjnym nie wprowadza się instytucji prawnych gwarancji zgodności z prawem.

Procesowe prawo administracyjne tworzy rozbudowany system instytucji prawnych gwarancji zgodnego z prawem działania organów administracji publicznej i to zarówno instytucji prawnych działania zgodnego $\mathrm{z}$ prawem, jak i instytucji prawnych następstw prawnych naruszenia prawa przez pozbawienie mocy obowiązującej aktu kształtującego uprawnienia lub obowiązki strony postępowania administracyjnego.
\end{abstract}

Słowa kluczowe: instytucje prawne, gwarancje, niezgodność z prawem, niepomijalność, zakres unormowania.

Zgodność z prawem jest jedną z podstawowych wartości w wykonywaniu zadań publicznych przez administrację publiczną. Takie znaczenie przypisuje tej wartości zarówno doktryna prawa administracyjnego, jak i regulacja prawa admi- 
nistracyjnego. Wypracowanie koncepcji zgodności z prawem działania administracji publicznej miało pierwotnie uzasadnienie w ukształtowaniu relacji prawnej między administracją publiczną a jednostką w formie władczej aktu administracyjnego. Uzasadniało to początek wypracowania koncepcji zgodności z prawem aktu administracyjnego, która następnie przenoszona jest na inne formy działania administracji publicznej ${ }^{1}$. Ostateczny kształt prawny tej koncepcji nadaje ustawodawca, przyjmując reżim bezwzględnej ochrony zgodności z prawem lub względny reżim zgodności z prawem. Wprowadzenie do systemu regulacji prawa administracyjnego gwarancji zgodności z prawem to zatem niepomijalny przedmiot regulacji ustrojowego, materialnego i procesowego prawa administracyjnego. Ostrze instytucji prawnych gwarancji zgodnego z prawem działania może być skierowane wobec osób wykonujących administrację publiczną, co jest właściwe przede wszystkim regulacji ustrojowego prawa administracyjnego przez pozbawienie zdolności do wykonywania kompetencji oraz przeciwko podjętemu działaniu w określonej formie prawnej, co z kolei jest przedmiotem regulacji materialnego i procesowego prawa administracyjnego.

Ta cecha niepomijalności wprowadzenia do regulacji prawa administracyjnego instytucji prawnych gwarancji zgodności z prawem wykonywania zadań administracji publicznej towarzyszy współczesnej regulacji, która odchodzi od klasycznej koncepcji władztwa administracyjnego, przypisując jednostce zdolność do kształtowania podjętą czynnością uprawnień lub obowiązków. Budowa instytucji prawnych gwarancji zgodności z prawem może być prosta lub złożona — przez poddanie czynności jednostki kontroli, uzależniając jej skutki prawne od zgodności z prawem ocenianej przez właściwy organ, lub przez przyznanie skuteczności prawnej czynności, ale z dopuszczalnością jej weryfikacji.

Rozwiązaniom prawnym przyjmującym dopuszczalność kształtowania uprawnień i obowiązków jednostki na podstawie czynności materialnoprawnej jednostki jako niepomijalny element towarzyszyło i towarzyszy wprowadzenie instytucji prawnych gwarancji zgodności z prawem. Budowa tych gwarancji zgodności z prawem czynności jednostki oparta jest na instytucji prawnej władczego pozbawienia skutku prawnego przez właściwy organ administracji publicznej. Instytucja prawna pozbawienia skutku prawnego czynności materialnoprawnej jednostki może opierać się na przyjęciu, że w razie niezgodności z prawem tej czynności następuje władcze ukształtowanie uprawnienia lub obowiązku decyzją admini-

1 B. Adamiak, Wadliwość decyzji administracyjnej, Wrocław 1986, s. 11 n. oraz podana tam literatura. 
stracyjną bądź że konsekwencją takiego stanu rzeczy jest zgłoszenie sprzeciwu w formie decyzji. Takie zróżnicowanie rozwiązań przyjmuje materialne prawo administracyjne.

Pierwsze rozwiązanie prawne, w swojej konstrukcji prawnej zbliżone do koncepcji samoobliczenia podatkowego, przyjmuje chociażby ustawa z dnia 20 stycznia 2005 roku o recyklingu pojazdów wycofanych $\mathrm{z}$ eksploatacji ${ }^{2}$, regulując obowiązek opłaty za brak sieci. Zgodnie z art. 15 tej ustawy „Wprowadzający pojazd sporządza roczne sprawozdanie zawierające informacje, o których mowa w art. 73 ust. 2 pkt 1 i 4 ustawy z dnia 14 grudnia 2012 r. o odpadach, na zasadach i trybie określonych w tej ustawie". Natomiast według art. 73 ust. 2 pkt 4 ustawy z dnia 14 grudnia 2012 roku o odpadach ${ }^{3}$ w rocznym sprawozdaniu w zakresie pojazdów zawarta jest informacja o wysokości należnej opłaty za brak sieci zbierania pojazdów. Obowiązek obliczenia opłaty za brak sieci powstaje na koniec roku kalendarzowego (art. 16 ustawy o recyklingu pojazdów wycofanych z eksploatacji). Wprowadzający pojazd określa wysokość opłaty według reguł przyjętych w przepisach prawa i obowiązany jest do jej wpłacenia do 31 marca roku następnego po roku, którego opłata dotyczy. Ustalona wysokość opłaty podlega kontroli z następstwami prawnymi władczego określenia jej wysokości. Według art. 17 ust. 1 ustawy o recyklingu pojazdów wycofanych z eksploatacji „W przypadku stwierdzenia, że wprowadzający pojazd, mimo ciążącego na nim obowiązku, nie uiścił opłaty za brak sieci albo uiścił opłatę w wysokości niższej od należnej, Główny Inspektor Ochrony Środowiska wydaje decyzję, w której określa wysokość zobowiązania z tytułu opłaty za brak sieci”.

Złożoną budowę instytucji prawnej gwarancji zgodności z prawem czynności jednostki przyjmuje ustawa z dnia 7 lipca 1994 roku Prawo budowlane ${ }^{4}$. Odchodząc od reguły władczego działania organów administracji publicznej przyjętej w art. 28 ust. 1, że roboty budowlane można rozpocząć jedynie na podstawie decyzji o pozwoleniu na budowę, zastrzeżono dopuszczalność wyjątków przez odejście od władczego działania na rzecz nabycia uprawnienia na podstawie czynności materialnoprawnej zgłoszenia inwestora w określonym zakresie przedmiotowym robót budowlanych wyznaczonym w art. 30 ust. 1, regulując wymogi materialne tej czynności (art. 30 ust. 2-4a-c). Czynność zgłoszenia obwarowana jest podwójną gwarancją zgodności z prawem. Po pierwsze, przez poddanie ocenie zgodności czynności zgłoszenia z przepisami prawa przeprowadzonej przez organ administracji architektoniczno-budowlanej. Według art. 30 ust. 5 tej ustawy

Zgłoszenia, o którym mowa w ust. 1, należy dokonać przed terminem zamierzonego rozpoczęcia robót budowlanych. Organ administracji architektoniczno-budowlanej, w terminie 21 dni od dnia doręczenia zgłoszenia, może, w drodze decyzji, wnieść sprzeciw. Do wykonywania robót

\footnotetext{
2 Dz.U. z 2019 r. poz. 1610 z późn. zm.

3 Dz.U. z 2020 r. poz. 797.

${ }^{4}$ Dz.U. z 2019 r. poz. 1186 z późn. zm.
} 
budowlanych można przystąpić, jeżeli organ administracji architektoniczno-budowlanej nie wniósł sprzeciwu w tym terminie.

Dla skuteczności prawnej czynności materialnoprawnej zgłoszenia istotne jest wyznaczenie przesłanek kontroli zgodności z prawem czynności. Zgodnie z art. 30 ust. 6 ustawy Prawo budowlane

Organ administracji architektoniczno-budowlanej wnosi sprzeciw, jeżeli: 1) zgłoszenie dotyczy budowy lub wykonywania robót budowlanych objętych obowiązkiem uzyskania pozwolenia na budowę; 2) budowa lub wykonywanie robót budowlanych objętych zgłoszeniem narusza ustalenia miejscowego planu zagospodarowania przestrzennego, decyzji o warunkach zabudowy, inne akty prawa miejscowego lub inne przepisy; 3) zgłoszenie dotyczy budowy tymczasowego obiektu budowlanego, o którym mowa w art. 29 ust. 1 pkt 12, w miejscu, w którym taki obiekt istnieje.

Dla oceny zgodności z prawem czynności zgłoszenia ma również znaczenie regulacja art. 30 ust. 7 tej ustawy, zgodnie z którą

Organ administracji architektoniczno-budowlanej może nałożyć, w drodze decyzji, o której mowa w ust. 5, obowiązek uzyskania pozwolenia na wykonanie określonego obiektu lub robót budowlanych objętych obowiązkiem zgłoszenia, o którym mowa w ust. 1, jeżeli ich realizacja może naruszać ustalenia miejscowego planu zagospodarowania przestrzennego, decyzji o warunkach zabudowy lub spowodować: 1) zagrożenie bezpieczeństwa ludzi lub mienia; 2) pogorszenie stanu środowiska lub stanu zachowania zabytków; 3) pogorszenie warunków zdrowotno-sanitarnych; 4) wprowadzenie, utrwalenie bądź zwiększenie ograniczeń lub uciążliwości dla terenów sąsiednich.

Budowę instytucji prawnej zgodności z prawem czynności zgłoszenia opartej na kontroli organu administracji architektoniczno-budowlanej wyposażonej w kompetencję do zamknięcia skuteczności czynności zgłoszeniem w formie decyzji sprzeciwu uznano za niewystarczającą, a w konsekwencji uzupełniono przez przyznanie kompetencji organom nadzoru budowlanego. Zgodnie z art. 50 ust. 1 pkt 3 organy nadzoru budowlanego mają właściwość do kontroli, czy czynność zgłoszenia mieści się w granicach dopuszczalnych przepisami prawa, określonych w art. 30 ust. 1 ustawy Prawo budowlane. Podkreślił to Naczelny Sąd Administracyjny w wyroku z dnia 24 stycznia 2018 roku:

nadzór budowlany nie może kontrolować zgłoszenia robót budowlanych pod kątem zachowania wymogów formalnych określonych przepisami art. 30 ust. 2 prawa budowlanego. Kontroli w tym zakresie dokonuje wyłącznie organ architektoniczno-budowlany, do którego wpływa zgłoszenie, i to tylko on jest uprawniony na podstawie przepisów ustawy do żądania uzupełnienia braków zgłoszenia. Organy nadzoru budowlanego właściwe są do prowadzenia tak zwanego postępowania naprawczego, sprawdzają między innymi, czy roboty budowlane nie zostały wykonane w sposób istotnie odbiegający od ustaleń i warunków określonych w przepisach. W przedmiotowej sprawie inwestor wykonanych robót budowlanych legitymował się skutecznie przyjętym przez Urząd Miasta $\mathrm{w}[\ldots]$ - Wydział Urbanistyki i Administracji Budowlanej zgłoszeniem. Tym samym należy uznać, że zrealizowane roboty nie były wykonane w warunkach samowoli budowlanej. Właściwy organ nie wydawał postanowienia o uzupełnieniu wniosku, w tym także nie miał wątpliwości do złożonego oświadczenia o prawie dysponowania nieruchomością na cele budowlane, nie była też wydawana decyzja wnosząca sprzeciw do wykonania zamierzenia, co potwierdza jednoznacznie, że zgłoszenie zostało skutecznie przyjęte. 
Jeszcze raz wyraźnie podkreślić należy, że organ nadzoru budowlanego nie ma uprawnień do badania zgodności z prawem zgłoszenia robót budowlanych, poza wyjątkiem wynikającym z art. 50 ust. 1 pkt 3 Prawa budowlanego. Z treści art. 51 ust. 1 i ust. 7, a także art. 83 Prawa budowlanego wynika, że organ nadzoru budowlanego jest właściwy do prowadzenia tak zwanego postępowania naprawczego $\mathrm{w}$ odniesieniu do robót budowlanych wykonywanych lub wykonanych na podstawie zgłoszenia z naruszeniem art. 30 ust. 1 Prawa budowlanego. W powołanym art. 30 ust. 1 Prawa budowlanego określono przypadki, w których roboty budowlane niewymagające pozwolenia na budowę wymagają zgłoszenia właściwemu organowi administracji. Oznacza to, że nadzór budowlany może jedynie kontrolować, czy zgłoszenie dotyczyło robót budowlanych, które wymagały zgłoszenia. Jeżeli okazałoby się, że na podstawie zgłoszenia wykonano roboty budowlane wymagające pozwolenia na budowę, to nadzór budowlany na podstawie art. 50 ust. 1 pkt 3 Prawa budowlanego może wszcząć tak zwane postępowanie naprawcze (art. 51 ust. 1 Prawa budowlanego). Z powyższego wynika, że nadzór budowlany nie może kontrolować zgłoszenia robót budowlanych pod kątem zachowania wymogów formalnych ${ }^{5}$.

To ograniczenie właściwości organu nadzoru budowlanego nie może jednak podważyć, że kontrola zgodności z prawem dotyczy zasadniczej kwestii dopuszczalności czynności materialnoprawnej zgłoszenia jako dopuszczalnej formy kształtowania uprawnienia. Jest to zasadniczą podstawą oceny zgodności z prawem organu architektoniczno-budowlanego, który obowiązany jest ustalić, czy roboty budowlane nie są objęte obowiązkiem uzyskania pozwolenia na budowę. Niewyrażenie sprzeciwu organu architektoniczno-budowlanego nie wyłącza w przypadku wadliwego działania tego organu zastosowania środków przez organ nadzoru budowlanego doprowadzenia do stanu zgodnego z prawem.

\section{III}

W procesowym prawie administracyjnym realizowana jest niepomijalność regulacji instytucji prawnych zgodności z prawem czynności w toku postępowania i rozstrzygnięć sprawy w postępowaniu. Zapowiedź wprowadzenia tych instytucji jest już wyrażona w zasadach ogólnych, przede wszystkim w zasadzie ogólnej praworządności (art. 6 kodeksu postępowania administracyjnego) oraz zasadzie ogólnej kontroli i nadzoru nad przestrzeganiem prawa (art. 7 norma pierwsza kodeksu postępowania administracyjnego). Zasada ogólna praworządności skierowana jest do działania organu administracji publicznej. Według art. 6 k.p.a. „Organy administracji publicznej działają na podstawie przepisów prawa”. Szerszy zakres ma zasada ogólna kontroli i nadzoru nad przestrzeganiem prawa. Zgodnie z normą pierwszą art. 7 k.p.a. „W toku postępowania organy administracji publicznej stoją na straży praworządności”. Zarówno z zasady ogólnej praworządności, jak i zasady ogólnej kontroli i nadzoru nad przestrzeganiem prawa wynika, że wymóg zgodności z prawem, nawet jeżeli jest adresowany wprost do

5 Wyrok NSA z dnia 24 stycznia 2018 roku, sygn. II OSK 1411/17, LEX nr 2452184. 
działania organu administracji publicznej, obejmuje pośrednio wymóg zgodności z prawem podejmowanych przez stronę (strony) czynności. O skuteczności czynności strony podjętej w postępowaniu przesądza organ administracji publicznej. Obejmuje to nie tylko zgodność z prawem czynności procesowych, ale też w przyjętym w administracyjnym prawie procesowym czynności materialnoprawnych.

Odchodząc od wyłączności rozstrzygnięcia sprawy indywidualnej decyzją administracyjną przez dopuszczenie ugody, nie pominięto ustanowienia gwarancji zgodności z prawem. Treść ugody wyznacza zgodne oświadczenie strony, lecz granicą tego zgodnego oświadczenia stron jest nienaruszenie prawa. Przestrzeganie tej granicy poddane jest kontroli organu administracji publicznej przez ustanowienie warunku skuteczności ugody. Zgodnie z art. 118 k.p.a. organ administracji publicznej odmawia zatwierdzenia ugody zawartej z naruszeniem prawa.

Ten niepomijalny element występuje także $\mathrm{w}$ regulacji instytucji prawnej mediacji. Według art. 96n $§ 1$ k.p.a. „Jeżeli w wyniku mediacji zostaną dokonane ustalenia dotyczące załatwienia sprawy w granicach obowiązującego prawa, organ administracji publicznej załatwia sprawę zgodnie z tymi ustaleniami, zawartymi w protokole z przebiegu mediacji”. Tak wyznaczone granice znaczenia prawnego ustaleń mediacji gwarantują zgodność z prawem podjętych działań organu administracji publicznej. Tylko gdy wynik mediacji mieści się w granicach obowiązującego prawa, organ może przyjąć dla przesądzenia o treści rozstrzygnięcia w decyzji administracyjnej.

Wprowadzona ustawą z dnia 7 kwietnia 2017 roku o zmianie ustawy Kodeks postępowania administracyjnego oraz niektórych innych ustaw ${ }^{6}$ instytucja milczącego załatwienia sprawy również zawiera niepomijalny element regulacji zgodności z prawem. Instytucja milczącego załatwienia sprawy nie została zaimplementowana jako odrębna forma załatwienia sprawy indywidualnej, lecz jest formą będącą gwarancją prawną przed bezczynnością organu administracji publicznej. Zgodnie bowiem $\mathrm{z}$ art. 122a $\S 2$ k.p.a.

Sprawę uznaje się za załatwioną milcząco w sposób w całości uwzględniający żądanie strony, jeżeli w terminie miesiąca od dnia doręczenia żądania strony właściwemu organowi administracji publicznej albo innym terminie określonym w przepisie szczególnym organ ten: 1) nie wyda decyzji lub postanowienia kończącego postępowanie w sprawie (milczące zakończenie postępowania) albo 2) nie wniesie sprzeciwu w drodze decyzji (milcząca zgoda).

Milczące załatwienie sprawy wchodzi w miejsce decyzji, w granicach dopuszczalnych przepisem szczególnym (art. 122a § 1 k.p.a.). Wchodząc w miejsce decyzji, musi jednak spełniać wyznaczone dla decyzji przesłanki zgodności z prawem, a zatem zgodności z przepisami prawa materialnego, oraz przepisami prawa procesowego, $\mathrm{z}$ tym że w tym zakresie wprowadzone są wyjątki (art. 122d $\S 1$ k.p.a.). Tę zgodność z prawem stwierdza organ administracji publicznej w adnotacji o milczącym załatwieniu sprawy, w której wskazuje treść rozstrzygnięcia

6 Dz.U. poz. 935. 
oraz jego podstawę prawną. Ten element wskazania treści rozstrzygnięcia i podstawy prawnej rozstrzygnięcia zawiera wydane w formie postanowienia na wniosek strony zaświadczenie o milczącym załatwieniu sprawy (art. 122f $\S 3$ pkt 3 k.p.a.). Wprowadzając instytucję milczącego załatwienia sprawy, której treść wyznacza żądanie strony, jak podkreślono, musi pozostawać w granicach zgodności z przepisami prawa. Budowanie gwarancji zgodności z prawem oparto na nadzwyczajnych trybach postępowania administracyjnego. Wymóg w adnotacji, czy wydanym w formie postanowienia zaświadczeniu o milczącym załatwieniu sprawy, oraz wskazania podstawy prawnej należy odnieść do przytoczenia przepisu prawnego, który dopuszcza milczące załatwienie sprawy, a nie do podstawy prawnej treści rozstrzygnięcia. Organ administracji publicznej nie może pozbawić mocy prawnej milczącego załatwienia sprawy poza nadzwyczajnymi trybami postępowania administracyjnego. Zgodnie z art. 122g k.p.a. „Do spraw załatwionych milcząco przepisy rozdziałów 12 i 13 w dziale II stosuje się odpowiednio. Przyjmuje się, że skutek wydania decyzji ostatecznej powstał w terminie czternastu dni od dnia upływu terminu, o którym mowa w art. 122c $\S 1$ ". W przypadku milczącego załatwienia sprawy gwarancje zgodności z prawem zostały zatem przesunięte nie na odmowę przyznania skuteczności prawnej milczącego załatwienia sprawy, a na pozbawienie skuteczności prawnej milczącego załatwienia sprawy. Wyprowadzenie naruszenia przepisów materialnego prawa czy naruszenia przepisów postępowania w zależności od ciężaru naruszenia otwiera organowi administracji publicznej dopuszczalność zastosowania właściwego trybu nadzwyczajnego postępowania.

Artykuł 122g stanowi o odpowiednim stosowaniu przepisów regulujących tryby nadzwyczajne, co jest związane z koniecznością dostosowania do szczególnego trybu milczącego załatwienia sprawy. Szczególny tryb milczącego załatwienia sprawy wyznacza przyjęte rozwiązanie w art. 122a $\S 1$ k.p.a. „Sprawę uznaje się za załatwioną milcząco w sposób w całości uwzględniający żądanie strony”. Treść rozstrzygnięcia sprawy jest wyznaczona żądaniem strony. Szczególny tryb milczącego załatwienia sprawy polega zatem na tym, że treść rozstrzygnięcia nie jest wyznaczona przepisem materialnego prawa, którego autorytatywną konkretyzację przeprowadza organ administracji publicznej w ustaleniu stanu faktycznego zgodnie z wymogami przepisów prawa procesowego. Takie oderwanie treści milczącego załatwienia sprawy od obowiązującej zasady ogólnej praworządności w wykonaniu administracji publicznej uzasadniało wprowadzenie koniecznego elementu do koncepcji milczącego załatwienia sprawy przez poddanie weryfikacji. Tworzy to podstawy realizacji zasady ogólnej kontroli i nadzoru nad przestrzeganiem prawa w postępowaniu administracyjnym. Milczące załatwienie sprawy wchodzi do obrotu prawnego i ma przypisaną cechę mocy decyzji ostatecznej. Pozostanie w obrocie prawnym uzależnione jest zgodnością z prawem w granicach wyznaczonych rodzajami naruszenia prawa dającymi podstawę zastosowania sankcji wzruszalności w razie kwalifikowanego naruszenia przepisów prawa 
procesowego, a w razie kwalifikowanego naruszenia przepisów prawa materialnego dającymi podstawę zastosowania sankcji nieważności. Przyjęcie w art. 122g stosowania odpowiednich do milczącego załatwienia sprawy przepisów rozdziału 12 i 13 działu II k.p.a. przesądza, że w zasadzie można przyjąć, że będą miały one zastosowanie wprost.

Wadliwość milczącego załatwienia sprawy może być wynikiem nie tylko naruszenia wprost przepisów prawa, ale też naruszenia prawa pośredniego. Z takim pośrednim naruszeniem prawa będziemy mieli do czynienia, gdy po wniesieniu podania organ administracji publicznej, który nie jest właściwy w sprawie, nie przekaże podania do organu właściwego (art. $156 \S 1$ pkt 1 k.p.a.) lub nie wyłączy się od załatwienia sprawy (art. $145 \S 1$ pkt 2 k.p.a.). Niezastosowanie tych obligatoryjnych obowiązków organu administracji publicznej przesądza o wadliwości milczącego załatwienia sprawy. Jedynie w razie gdy przepis regulujący milczące załatwienie sprawy wyłącza stosowanie przepisów postępowania, nie można wywodzić z tych przepisów wadliwości milczącego załatwienia sprawy. Takim przykładem jest wyłączenie art. 10 k.p.a. regulującego zasadę ogólną czynnego udziału strony w postępowaniu, co wyklucza zastosowanie sankcji wzruszalności milczącego załatwienia sprawy na podstawie art. $145 \S 1$ pkt 4 k.p.a.

Wprowadzając do formy rozstrzygnięcia sprawy milczące załatwienie sprawy, nie pominięto wprowadzenia instytucji prawnych gwarancji zgodności z prawem.

\section{IV}

W prawie administracyjnym niepomijalnym elementem jego regulacji są instytucje prawne gwarancji zgodności z prawem działania organów administracji publicznej. W prawie ustrojowym regulacja instytucji kontroli tworzy gwarancje zgodnego z prawem działania. O jej znaczeniu przesądza wyodrębnienie regulacji właściwości wojewody wykonywania kontroli w art. 28 ustawy z dnia 23 stycznia 2009 roku o wojewodzie i administracji rządowej w województwie ${ }^{7}$ i szczegółowej regulacji jej trybu ustawą z dnia 15 lipca 2011 roku o kontroli w administracji rządowej ${ }^{8}$. W regulacji kontroli w administracji rządowej jednym z podstawowych kryteriów jest kryterium kontroli działania pod względem legalności. Kontrola administracji rządowej uzupełniona jest instytucją nadzoru. Mianowicie, w zakresie aktów prawa miejscowego zgodnie z art. 61 ust. 1 ustawy o wojewodzie i administracji rządowej w województwie

Prezes Rady Ministrów uchyla, w trybie nadzoru, akty prawa miejscowego, w tym rozporządzenia porządkowe, ustanowione przez wojewodę lub organy niezespolonej administracji rządowej,

7 Dz.U. z 2019 r. poz. 1464.

8 Dz.U. z 2020 r. poz. 224. 
jeżeli są one niezgodne $\mathrm{z}$ ustawami lub aktami wydanymi w celu ich wykonania, a także może je uchylać z powodu niezgodności z polityką Rady Ministrów lub naruszenia zasad rzetelności i gospodarności.

W prawie ustrojowym samorządu terytorialnego znajduje to wyraz w regulacji nadzoru, którego podstawowym kryterium jest zgodność z prawem (art. 85 ustawy z dnia 8 marca 1990 roku o samorządzie gminnym ${ }^{9}$, art. 77 ustawy z dnia 5 czerwca 1998 roku o samorządzie powiatowym ${ }^{10}$, art. 79 ustawy z dnia 5 czerwca 1998 roku o samorządzie województwa ${ }^{11}$ ) i konsekwentnie na tej podstawie stosowane są środki nadzorcze. Zgodnie więc z art. 91 ust. 1 ustawy o samorządzie gminnym „Uchwała lub zarządzenie organu gminy sprzeczne z prawem są nieważne. O nieważności uchwały lub zarządzenia w całości lub w części orzeka organ nadzoru w terminie nie dłuższym niż 30 dni od dnia doręczenia uchwały lub zarządzenia, w trybie określonym w art. 90”. Po upływie terminu gwarancja przesuwa się na prawo zaskarżenia do sądu administracyjnego (art. 93 ust. 1 ustawy o samorządzie gminnym). Na konstrukcji zgodności z prawem oparte są środki nadzorcze stosowane wobec organów (art. 96 i 97 ustawy o samorządzie gminnym). Takie rozwiązanie przyjmują również ustawa o samorządzie powiatowym (art. 79, 83 i 94) oraz ustawa o samorządzie województwa (art. 82, 84 i 85).

W materialnym prawie administracyjnym niepomijalność regulacji instytucji prawnych gwarancji zgodności z prawem co do zasady należy łączyć z regulacją $\mathrm{w}$ procesowym prawie administracyjnym. To $\mathrm{w}$ prawie procesowym zawarte jest bowiem unormowanie sankcji za naruszenie przepisów prawa materialnego. Nie oznacza to, że w materialnym prawie administracyjnym nie wprowadza się instytucji prawnych gwarancji zgodności z prawem. Dotyczy to tych rozwiązań prawnych, które odchodzą od klasycznego układu władztwa administracyjnego na rzecz kształtowania uprawnień lub obowiązków czynnością materialnoprawną jednostki. Gwarancją zgodności z prawem jest poddanie tej czynności ocenie zgodności z prawem przez organ administracji publicznej i w razie ustalenia naruszenia prawa pozbawienie jej skutku prawnego.

Procesowe prawo administracyjne tworzy rozbudowany system instytucji prawnych gwarancji zgodnego z prawem działania organów administracji publicznej i to zarówno instytucji prawnych działania zgodnego z prawem, jak i instytucji prawnych następstw prawnych naruszenia prawa przez pozbawienie mocy obowiązującej aktu kształtującego uprawnienia lub obowiązki strony postępowania administracyjnego.

Niepomijalnym elementem $\mathrm{w}$ regulacji prawa administracyjnego są zatem instytucje prawne gwarancji zgodnego z prawem wykonywania tego prawa. Ma to w pełni umocowanie w przyjętych wartościach w Konstytucji Rzeczypospolitej Polskiej.

9 Dz.U. z 2020 r. poz. 713.

10 Dz.U. z 2019 r. poz. 511 z późn. zm.

11 Dz.U. z 2019 r. poz. 512 z późn. zm. 


\title{
Bibliografia
}

Adamiak B., Wadliwość decyzji administracyjnej, Wrocław 1986.

\section{Legal institutions which guarantee compliance with the law as an unavoidable element of administrative law}

\begin{abstract}
Summary
Legal institutions which guarantee that the operations of public administration bodies comply with the law are an unavoidable element of administrative law. In organic law, the regulation of control institutions and the admissibility of applying supervision measures creates guarantees of lawful operation. It is introduced both in the organic regulation of central government administration and in the systemic regulation of local government.

In substantive administrative law, the unavoidability of the regulations of legal institutions which guarantee compliance with the law, as a rule, should be combined with the regulation in administrative procedural law. It is procedural law that regulates sanctions for violation of substantive law. This does not mean that substantive administrative law does not introduce legal institutions to guarantee compliance with the law.

Administrative procedural law creates an extensive system of legal institutions that guarantee the lawful operation of public administration bodies. This applies both to the legal institutions of lawful operation and the legal institutions of the legal consequences of a violation of the law by depriving the binding force of an act setting out the rights or obligations of a party to administrative proceedings.
\end{abstract}

Keywords: legal institutions, guarantees, non-compliance with the law, non-passing, scope of the regulation. 